\title{
1. The backdrop to EU Cohesion Policy debates: Europe 2020 and the post-crisis economy
}

\subsection{INTRODUCTION TO THE BACKDROP TO EU COHESION POLICY DEBATES}

One of the flagship policies of the European Union (EU) is 'Cohesion Policy', which is the regional and urban development policy of the European Union. This book aims to explain the role played by EU regional and urban policy, its role within the wider EU system (European Union 2012; Pinder and Usherwood 2007), and also the ideas which underpin the recent reforms to the policy. While there are obviously many local, regional and urban policy initiatives which take place within the national context and which are independent of EU initiatives, it is those local development initiatives which are related in part to EU funding schemes which are the specific focus of this book.

In general, the level of awareness on the part of the public of the role and impacts of EU Cohesion Policy is closely related to the relative scale of EU Cohesion Policy interventions in their own countries (European Commission 2010a). Not surprisingly, therefore, in the richer Northern and Western European nations the overall levels of public awareness of the role and impacts of EU Cohesion Policy are much less than in the lower income countries of Central, Eastern and Southern Europe (ibid.). However, EU Cohesion Policy has for a long time been a key policy of the European Union, and one of its main levers for promoting the development of the EU. Today Cohesion Policy is the single largest policy of the European Union and therefore examining the nature, logic, role, goals, mechanisms, workings, impacts and outcomes of the policy is important in its own right for providing a good understanding of one of the most important activities in the European policy arena.

The key focus of this book, however, is on the reforms to EU Cohesion Policy and understanding the issues raised regarding the required reforms of the policy also allows us to address fundamental questions about the 
role played by economic geography in growth and development processes, as well as modern thinking regarding economic policy. Many of the issues raised in this book reflect crucial analytical and conceptual issues which are common to all aspects of economic geography and to all development policies operating at the regional, urban or local levels, and in all parts of the world. Some of the ideas which inform these debates have emerged relatively recently in response to new developments in the fields of urban and regional economics and economic geography. However, some of these issues are also based on longstanding traditions, so the intellectual inputs into the policy reform debates reflect a mixture of both old and new arguments. However, it is this particular mixture of old and new arguments which is novel, and renewed intellectual agendas challenge many preconceived approaches and assumptions regarding all aspects of these policies. Of particular interest here is the role which local context plays in questions of policy design. EU Cohesion Policy operates in a highly heterogeneous environment and an awareness of this heterogeneity allows us to examine different development policy arguments in different contexts, but from the standpoint of a single policy logic and architecture. As such, investigating the changes to EU Cohesion Policy opens up a broader set of discussions which are pertinent to wider development policy debates, including that of the European Union.

However, making a case for a policy or a case for its reform also requires a sound understanding of the earlier experience of the policy and the earlier arguments underpinning its existence and design. All current policies and their design are the result of a complex set of earlier issues and discussions, some of which are complementary to each other and some of which may be rather conflicting to each other. This is also the case for EU Cohesion Policy, and in this book we will address these various issues. However, at this stage it is necessary to underline the fact that policies also reflect a political economy process which takes place over time. As such, while many aspects of the policy-reform discussions examined here are relatively recent, the discussions regarding the links between European integration, the impacts on regions and role of policy in this arena, already have a longstanding pedigree based on a wellestablished tradition. This tradition reflects the different stages of European integration. There are various publications which reflect the geographical and regional aspects of the earlier stages of European economic integration following the establishment of the EU Single Market (Armstrong and Vickerman 1995; Button and Pentecost 1999; Cappelin and Batey 1993; Cheshire and Gordon 1995; Cole and Cole 1993; Delamaide 1994; Fingleton 2003). There is also material which discusses the complexities and heterogeneity of the EU context (Le Galès 
2002; Rodriguez-Pose 1998, 2002) as well as different aspects of previous generations of EU Cohesion Policy (Artobolevsky 1997; Bachtler and Turok 1997; Leonardi 2005; Martin 1999; Molle 2007; Vanhove 1999). There are also useful publications which help to position the EU regional and urban debates with respect to North American debates (Summers et al. 1999; Sweet 1999). Finally, there is also a more recent generation of publications which deal with particular issues facing the European regional and urban arena (Bellini and Hilpert 2013; Blokker and Dallago 2009; Faludi 2008; Hall and Pain 2006; Jovanović 2009; Sardadvar 2011; Stierle-Von Schütz et al. 2008; Zientara 2009) and specifically the Cohesion Policy negotiation environment (Bachtler et al. 2013). These publications add a great deal of detail, colour and nuance to the policy-reform discussions, alongside the numerous European Commission and European Union official publications and information tools (DG Regio 2013) referred to in this book.

A good knowledge of this wide-ranging literature offers a broad picture of the integration experience which Europe and its regions have undergone over recent decades, and helps to provide a sound and nuanced understanding of how the current context has been arrived at. This knowledge also helps us to sketch out a likely road-map of how the policy debates and the policy processes may evolve. The ideas and issues referred to in this established regional development literature are constantly referred to throughout this book, and knitted together as far as possible with the newer ideas emerging from a variety of different fields. This is necessary because over recent years there has emerged a wide-ranging debate regarding the role which regional and urban policy plays, can play or should play, in European integration processes and this debate re-engages with both these older and newer issues. The different aspects of these complex debates are discussed in detail throughout this book. However, before we engage in these discussions it is essential to highlight the key influences which heavily shape the backdrop to these discussions.

In order to begin our discussions it is necessary to point out that all of the debates regarding the reforms to European regional and urban policies need to be set against the backdrop of four important influences which both help to foster and also heavily shape these debates. These four influences are: (i) major steps forward in academic thinking about spatial economics, economic geography and development policy; (ii) the diversity and heterogeneity of the European Union context; (iii) shifts in European growth perspectives and the development of the Europe 2020 strategy; and (iv) the geographical impacts of the 2008 global financial crisis. The first of these four issues, namely the advances in thinking 
about economic geography and spatial economics, are discussed in detail throughout the following chapters of this book, and indeed are the key focus of this book, so they will not be discussed in this chapter. However, before moving on to these discussions it is useful for us to address the other three issues briefly here, so as to provide a sound basis for our subsequent discussions and to properly situate the discussions about the reforms to EU Cohesion Policy.

\subsection{THE DIVERSITY AND HETEROGENEITY OF THE EUROPEAN UNION}

The European Union (EU) is a diverse economic, social and territorial arena. European Integration is a slow process with important break-points and thresholds defining critical stages. As of 2014 the EU is made up of 28 countries, known as 'member states', comprising what are known as the 'EU-15' mixed economy countries which had joined the EU by 1995, the 'EU-12 accession' countries which had joined from 2004 onwards of which ten were former transition economies plus Malta and Cyprus, and finally Croatia which joined in 2013. The degree of heterogeneity of the European context, and the context in which EU Cohesion Policy operates, can be understood initially simply by considering the national productivity variations within the EU. In 2014, the EU-wide average per capita GDP is just approximately $€ 25,500$ (US $\$ 34,000^{1}$ ), while the national per capita GDP ranges between approximately $€ 11,000$ (US\$14,000) in Bulgaria and Romania to some $€ 66,000$ (US\$89,000) in Luxembourg, which is then followed by a group of countries comprising The Netherlands, Denmark, Ireland, Austria, Germany and Sweden, all of whose per capita GDP levels are of the order of approximately $€ 33,000$ (US\$42,000). A group of EU member states including The Netherlands, Belgium and Denmark, exhibit some of the highest levels of labour productivity per hour in the OECD (OECD 2014). Belgium and Finland have GDP per capita figures around $€ 30,000$ (US\$40,000) while the UK and France both have per capital GDP levels of the order of €28,000 (US\$36,000), followed by Italy $€ 26,000$ (\$US34,000) and Spain with per capita GDP levels of approximately $€ 24,500$ (US\$32,000). The rest of the former transition economies exhibit productivity levels of between just over $€ 15,000$ (US\$20,000) in Latvia to $€ 21,000$ (US\$28,000) in Slovenia. Finally, in the wake of the 2008 global financial crisis both Portugal and Greece now have GDP per-capita levels approximately of $€ 19,000$ (US\$26,000) and as such are now between the levels exhibited by the former transition economies of the Czech Republic €20,700 
(US\$27,500) and Slovenia. What becomes very clear from these figures is that the diversity and inequality within the EU is much greater than that which exists within the USA, Canada, Australasia, Japan or Korea, while at the same time it is much less than that which exists in the BRICS (Brazil, Russia, India, China and South Africa) countries (Iammarino and McCann 2013; McCann 2009; OECD 2011a, b, 2014). The Europe regional system displays features which combine elements from many different parts of the world, but in a manner which is specific to Europe. In particular, the heterogeneity of the EU interregional system is unique, in that within a single integrated market the variation in national and regional per-capita incomes almost exactly reflects the national and regional per-capita income variations evident across the whole of the OECD. Understanding these variations is important in order to ensure a correct positioning of discussions regarding the European interregional context in terms of different parts of the global economy. By setting the EU regional discussions within this comparative context we are better able to ensure that our discussions are properly grounded, in that the EU interregional variations are far greater than are evident in the USA or Canadian context, and equivalent to those evident in the North American context including Mexico.

Allowing for this heterogeneity, the EU is now already a highly integrated economic arena. Most recent estimates suggest that the positive impact of the EU Single Market on national economies with estimates for EU different countries varying between 3-10 per cent of GDP with most estimates being of the order of 5-6 per cent of GDP (BIS 2011; BIS/DFID 2011; Boltho and Eichengreen 2008; CBI 2013). While these numbers may not sound large to some observers and may be less than some optimistic forecasters might have expected, for comparison purposes these percentage changes in GDP are more than comparable to: the contribution of railways to nineteenth-century US economic growth; ${ }^{2}$ equivalent to the potential economic growth effects of doubling of the size of a nation's cities; ${ }^{3}$ greater than the impacts of Asia's two-and-ahalf decades of growth on the Australasian economies; ${ }^{4}$ greater than the growth effects of NAFTA ${ }^{5}$ which was established a couple of years after the EU Single Market; similar to the growth contribution of Europe's ICT-producing sectors (Timmer et al. 2011) or the growth effects of investments non-ICT-capital on the EU-15 countries over the same period (Timmer et al. 2010; Van Ark et al. 2012); ${ }^{6}$ and many times greater than the negative output effects of the 2008 global financial crisis on the overall EU economies (OECD 2014). Viewed in the light of these other impacts, the Single Market effects are clearly very significant. 
At the same time, however, economic geography and industrial economics suggest that these impacts will vary markedly across countries and regions within the EU. A sense of the scale of the Single Market effect can be gained from the fact that in the case of The Netherlands the relevant estimates are equivalent to one month's extra salary per annum for Dutch workers, ${ }^{7}$ while for the UK these estimates are equivalent to three times the annual contribution of North Sea Oil to the UK economy ${ }^{8}$ and similar to the growth contribution of financial services to the UK economy over the period of the Single Market (Aghion et al. 2013). In addition, the full removal of the remaining intra-EU trade barriers, particularly in services, is expected to generate additional benefits ${ }^{9}$ of a similar order of magnitude (BIS 2011). As such, the existing benefits of the Single Market integration process are largely consistent with those predicted by the original analytical exercises (Cecchini et al. 1988; Commission of the European Communities 1990; Emerson et al. 1988, 1992), and if the Single Market is fully completed, this would be expected to generate total productivity benefits which are much greater than those which were originally forecast.

Today the integrated arena of the EU economy is characterised by dense cross-border flows of goods, services, people, capital and investment funds. These flows operate within networks of value chains spanning sectors and borders (Timmer et al. 2013) with the value-adding role of different countries changing (Jaegers et al. 2013) as productionrelated investments moves across borders. However, even allowing for the processes of out-sourcing, off-shoring and production fragmentation all of which are associated with modern globalisation (McCann 2008), it is still the case that the domestic value-added within the EU represents more than 85 per cent of the final value of EU consumer sales and this share is very similar to that which is observed for the USA and Japan (European Union 2013a). The reason is that over the last three decades the majority of these fragmentation processes have been reflected in shifts of value-adding followed by cross-border cross-hauling and re-importing to and from other EU countries, rather than to other parts of the world. This phenomenon of 'global regionalism', whereby neighbouring countries become increasingly integrated in all aspects of their economies, is a well-known outcome of the modern era of globalisation (Rugman 2000), and also reflects similar trends in other parts of the world (McCann 2013). The process of European integration is neither smooth nor a continuously forward-moving process, but rather a process which ebbs and flows. Although over time the process of economic integration has indeed progressed a long way, at the present time the current environment in Europe is very challenging. In particular, the 
fiscal and monetary issues evident within many of the Eurozone economies raise complex macroeconomic challenges. For the purposes of this book, however, it is not necessary to discuss many of the diverse challenges facing Europe. Rather, it is important to note that in spite of aspects of recent retrenchment in the post-crisis era, most evidence continues to point to increasing long-run international integration (Ghamawat and Altman 2012; MGI 2014; UNCTAD 2012) in Europe and elsewhere.

\subsection{THE EUROPE 2020 STRATEGY AND ITS REGIONAL AND URBAN DIMENSIONS}

In the case of Europe, any discussions regarding the role of EU Cohesion Policy must necessarily first be positioned against the backdrop of the overall EU policy agenda, which is known as the Europe 2020 strategy. In June 2010 the Council of the European Union approved the Europe 2020 strategy $^{10}$ (European Union 2011) and this strategy advocates that public policy should aim to promote smart, sustainable and inclusive growth (European Commission 2010b). The smart growth dimension includes improving the conditions for innovation, research and development and improving education levels; the sustainable growth dimension includes meeting climate change and energy objectives; and the inclusive growth dimension includes promoting employment and promoting social inclusion, in particular through the reduction of poverty (European Commission 2010b). This multidimensional approach is based on a growing awareness that successful and longstanding growth and development processes must necessarily incorporate these three different dimensions and that growth processes which are overly concentrated on only one or two of these development dimensions are unlikely to be viable in the long run. The Europe 2020 strategy of smart, sustainable and inclusive growth also closely mirrors the 2009 OECD 'Global Standard' growth strategy (OECD 2009a) of 'stronger, cleaner and fairer growth' 11 as well as recent international ${ }^{12}$ and US thinking ${ }^{13}$ leading to the US growth strategy of 'sustainable communities, innovation clusters, revitalizing neighborhoods'. ${ }^{14}$ Indeed, these various approaches all reflect a growing consensus that development needs to be environmentally aware, ${ }^{15}$ broad-based and inclusive in order to be long-lasting (Berg and Ostry 2011; Ezcurra 2007; Piketty 2014; The Economist 2014a) and that modern policy approaches to growth and development also need to consider these broader dimensions of environmental and social sustainability in order to be effective. ${ }^{16}$ These ideas have been gradually 
emerging over the last decade and reflect something of a shift away from the largely sectoral approach of the earlier 'Lisbon Strategy' which was originally launched in 2000 and re-launched in 2005 (João Rodrigues 2009), but whose results were widely viewed as disappointing (Bachtler et al. 2013; European Commission 2010c), including at the regional level (Dijkstra 2010).

The broader multi-dimensional approach to growth and development reflected in the Europe 2020 strategy also raises fundamental issues regarding the nature of growth and development processes at the local and regional levels. In particular, the complementarities and trade-offs between the different smart (stronger), sustainable (cleaner) and inclusive (fairer) growth dimensions differ between regions and localities (OECD 2011a) and these differences pose significant local and regional policy challenges. In the case of the EU these differences are very marked and an acknowledgement of these differences heavily shapes the debates regarding the role played by regions and cities in the long-run growth and development processes of the European Union. Yet, the thinking underpinning the different aspects of the Europe 2020 strategy at the regional level (DG Regio 2008, 2009a,b) as well as at the national and EU-wide levels, also very much pre-dates the 2008 global financial crisis. Over recent years there has emerged a broad-based consensus that EU Cohesion Policy is ideally positioned to play a key role in driving the Europe 2020 agenda. This is in part because Cohesion Policy already seeks to address smart, sustainable and inclusive challenges, and these all have explicitly spatial and local dimensions as also reflected in both OECD (2009a, 2011a) and US policy approaches. However, this consensus has also arisen in response to much reflection and a fundamental intellectual reconsideration of the role and nature of the policy during 2008-2009, as well as a widespread public consultation process. ${ }^{17}$

The Fifth Cohesion Report on Economic, Social and Territorial Cohesion (European Commission 2010d) proposed that regional, city and local authorities working in partnership with the both national governments and the EU through Cohesion Policy (European Union 2011) could help to drive many aspects of the Europe 2020 agenda. As we will see in this book, the EU-wide consultation exercise along with the deliberations within the European Commission (2011a), the European Parliaments and the European Council, demonstrates that these ideas were strongly supported across the European Union at many different national, regional, urban and local levels (CoR 2014). In the words of the European Commission President José Manuel Barroso, 'Cohesion Policy is one of the key instruments to realise the Europe 2020 goals. It is the largest EU investment in the real economy and a key pillar of the EU 
economic policy triangle of fiscal consolidation, structural reforms investment in growth' (European Commission 2014a). However, the idea that local, regional and urban actors implementing actions and interventions at the local, regional or urban scale can help to foster aggregate national growth and development, reflects thinking which has been undertaken again in a wide range of international arenas over a long period including Europe (Padoa-Schioppa et al. 1987), and most recently in particular at the level of the OECD (OECD 2009b, c; 2011a). These debates, however, regarding the nature of growth and development, the role of regions and cities in these development processes, and also the possibilities for modern policy initiatives to foster broad-based growth, have all recently been thrown into sharp relief by the 2008 global financial crisis. The aftermath of the crisis has witnessed dramatically differing fortunes amongst the regions of Europe, faltering progress towards Europe 2020 goals (European Commission 2014b), and a re-ordering or reshaping of regional trajectories.

\subsection{THE IMPACTS OF THE 2008 GLOBAL FINANCIAL CRISIS ON THE EU ECONOMIES}

The thinking underpinning the different aspects of the Europe 2020 strategy very much pre-date the 2008 global financial crisis, and reflect broader debates regarding the nature of growth and development processes and the role which policy can play in shaping these processes. However, the goals of the Europe 2020 strategy are also very pertinent to the challenges which have arisen in the aftermath of the 2008 global financial crisis (European Commission 2011b), and as such, the 2010 adoption of the strategy was especially timely. Across Europe the complex economic, social and political effects of European economic integration processes are well documented (Addison and Siebert 1997; Baldwin et al. 1999; Bliss and de Macedo 1990; Crafts and Toniolo 1996; Eichengreen 2007; Florio 2011; Jovanović 2005; Kahanec and Zimmerman 2011; Mayhew 1998; Rogowski et al. 2011; Rosamond 2000), as are the impacts on Europe of the global financial crisis, and the future options and challenges facing Europe in this arena are heavily debated (Alesina and Giavazzi 2006; Arestis and Sawyer 2012; Berglund et al. 2009; Fitoussi and Le Cacheux 2010; Marsh 2009; Pisani-Ferry 2014; The Economist, 2014b; Vaughan-Whitehead 2013; Zientara 2009). While an exhaustive discussion of these issues is not necessary here, as a preparation for engaging with the material in the following chapters in this book, it is useful to highlight some of the key effects of the global 
financial crisis which particularly impact on the regional and urban aspects of Europe.

For our purposes here, and drawing directly from the official publications of the European Union, it is useful to highlight four major features of the 2008 global financial crisis and its aftermath on the EU economies, namely: (i) the effects on sectors; (ii) the effects on foreign direct investment (FDI); (iii) the effects on poverty; and (iv) the effects on public finances.

(i) Although the global financial crisis of 2008 originated in the arenas of finance and insurance, most of its most severe and adverse impacts across the EU have been felt in other sectors, and in particular in the construction sector. While EU-wide output and employment in the finance and insurance sectors had again reached its 2007 levels by 2011, EU-wide gross value added (GVA) and employment in construction had fallen by 3 per cent between 2007 and 2011. In those countries most severely affected by the crisis, these contractions ranged between 6 per cent and 20 per cent, while property prices in these countries fell by $30-50$ per cent during this period (European Union 2011).

(ii) Much of the growth and economic convergence between member states in the two decades prior to the 2008 global financial crisis was associated with massive increases in intra-EU trade and inflows of Foreign Direct Investment (FDI), which spearheaded massive cross-border processes of technological transfer of all forms (World Bank 2012). In the years prior to the 2008 global financial crisis interregional trade in Europe increased rapidly (Thissen et al. 2013). At the same time, the inflows of FDI into EU member states originated both from outside of Europe, but also from within Europe, from other EU member states (McCann 2009). In 2004 some three-quarters of total FDI inflows into EU nations originated from other EU nations with one-quarter originating from outside of the EU. The scale of these inflows relative to national GDP was most marked in the EU-12 countries (MGI 2013), with the ratio of annual FDI inflows to national GDP being of the order of 15-23 per cent in 2005-2007 in Bulgaria, Estonia, Malta and Belgium (European Union 2013b). The cumulative result of these inflows over previous years meant that in 2004 the FDI stocks which originated from inside of the EU accounted for some 60 per cent of total EU FDI stocks, while some 40 per cent of the FDI stocks within the EU originated from outside of the EU (European Union 2013b). 
(iii) At a global scale, however, the major impacts of the 2008 global financial crisis were massive reductions in FDI flows and in some cases actual withdrawals and retrenchment of FDI stocks (Ghamawat and Altman 2012; UNCTAD 2012) and this was also the case within the EU. Europe experienced major falls in both inter-regional and cross-border trade followed by a slow recovery (Thissen et al. 2010), alongside similar falls in FDI. These effects were particularly marked in the case of some EU member states, with FDI flows falling between 2005 and 2007 by the equivalent of 1.5-6 per cent in many EU-12 member states, with Bulgaria experiencing a fall equivalent to 12 per cent of GDP (European Union 2013b). In 2011 the current FDI inflows into EU member states from both within the EU and from outside of the EU were running at some 60 per cent of their pre-crisis levels (European Union 2013b). These changes have been wrought primarily by sharp reductions in intra-EU FDI flows in the aftermath of the 2008 global financial crisis which have been more severe than the reductions in FDI inflows from outside of the EU. This reduction in intra-EU FDI inflows means that the relative size of FDI inflows into EU member states originating from within the EU and those originating from outside of the EU have shifted markedly. FDI inflows from outside of the EU now account for one-third of total FDI inflows into EU member states while two-thirds are still accounted for by inflows from within the EU. These changes in FDI flows have obviously heavily impacted on the distribution and scale of FDI stocks within the EU. By 2011 the FDI stocks within the EU which had originated from within the EU were only just over 50 per cent of total FDI stocks in the EU, while those which had originated from outside of the EU accounted for just under 50 per cent of total European FDI stocks (European Union 2013b). Recent evidence suggests that FDI flows in EU countries from other parts of Europe as well as from outside of Europe are again recovering to pre-crisis levels, and in particular in western Europe (Ernst and Young 2014).

(iv) The share of the population at risk of poverty or social exclusion has risen in almost every EU member state since 2008, except for Poland and Romania (European Union 2013b). The three major dimensions of this phenomenon are share of the population at risk of poverty, experiencing severe material deprivation, or experiencing very low work intensity. Prior to the 2008 global financial crisis disposable income had been growing rapidly in all countries, but the subsequent falls in disposable income in the wake of the crisis 
mean that real disposable income in many countries is now no higher than it was prior to 2005 (European Union 2013b), and in some cases no higher than it was prior to 2003. Similarly, the at-risk-of-poverty levels in many countries have again returned to pre-2005 levels, while the share of very low work intensity households is now greater than it was in 2005 in many countries (European Commission 2012).

(v) Since 2008 the levels of public debt relative to GDP have increased in every EU member state except Sweden (European Union 2013b). At present only four EU-15 countries, namely Sweden, Luxembourg, Finland and Denmark, have public levels below 60 per cent of GDP, while this is also the case for all of the EU-12 countries. However, some of the EU-12 countries with low levels of public debt, such as Estonia, have been severely affected by the crisis. Sub-national government investment as a share of total national public investment has tended to increase in decentralised countries and to decrease in centralised countries, although the long-run OECD-wide trend is towards decentralisation (OECD 2013a). In order to reduce their national debts public investment in many of these countries in productivity-enhancing arenas such as transport infrastructure, education, R\&D and innovation-related activities are being cut, such that gross fixed capital formation in 2013 is lower in $18 \mathrm{EU}$ member states than it was in 2011 (European Union 2013b). However, these public expenditure reductions also hide subtle shifts. In particular, a majority of EU member states have shifted towards capital expenditure and away from non-capital expenditure, while also increasing the relative share of sub-national government investments (Dotti and Bubbico 2014). At the same time, since the global financial crisis, the levels of public trust in national governments have fallen in the majority of European countries, and these falls are most notable in those countries facing severe government debt problems (OECD 2013b).

These four key features of the 2008 global financial crisis have led to both the stalling and the acceleration of the processes of European integration, both politically as well as economically. In economic terms the aftermath of the 2008 global financial crisis has in part reversed many of the benefits associated with increasing European economic integration which we have witnessed over the last two decades. However, although all sections of Europe have been adversely affected by the crisis, these effects have not been evenly distributed across Europe, but rather have tended to be concentrated in particular sectors, in particular countries and 
regions, and amongst particular sections of the population. The fact that the effects of the crisis are unevenly felt threatens the unity of the EU, because the benefits and costs of EU-wide economic integration are perceived differently in different parts of Europe. At the same time, the required urgent responses to the crisis have led to an acceleration of various institutional measures aimed at deepening the union and which are designed to allay future shocks. Many of these measures are unlikely to have taken place in other circumstances, and again, they heavily shape the arena in which EU Cohesion Policy operates.

It is the combination of the new policy thinking provided by the Europe 2020 strategy plus the new policy challenges thrown up by the impacts of the 2008 global financial crisis, which now provide the backdrop to all current debates about the nature and role of EU Cohesion Policy. The Europe 2020 strategy highlights the importance of the multi-dimensional nature of growth and development and the need for policy to be similarly multi-dimensional in its approach. At the same time, the post-crisis economy is one in which the integration processes of Europe are under severe strain, as are the economies of many regions which were previously very buoyant. The new thinking and the new realities together frame all current policy discussions. Although as we will see in this book the discussions regarding the case for regional and urban development policy at the level of the EU largely pre-date both the launch of the Europe 2020 strategy and also the onset of the 2008 global financial crisis, both of these developments have heavily shaped all subsequent discussions regarding the future nature, role and design of EU Cohesion Policy. Importantly, the new thinking and the new post-crisis context together provided an opportunity for fundamental policy reform debates to be aired, and for policies actually to be reformed after a long period of relatively little change.

\subsection{THE STRUCTURE AND LOGIC OF THE BOOK}

The aim of this book is to examine the various debates surrounding the reforms to EU regional and urban policy, or more specifically EU Cohesion Policy, and to explain the logic which underpins the outcomes of these debates. Any policy agenda, policy framework or policy approach such as Cohesion Policy which has to operate across very diverse environments and to respond to the enormously differing challenges associated with different parts of Europe, automatically faces immense challenges. Yet, these policy challenges are not only related to the range of different issues to be addressed and the range of different 
contexts in which these issues are situated, but also to intellectual challenges regarding the modern case for these policies and the contemporary role which economic development policy can play in diverse situations. Having sketched out here the major features of Europe's diversity and heterogeneity, the Europe 2020 strategy and also some of the key impacts of the 2008 global financial crisis in Europe, we are now in a position to begin a serious discussion regarding the role, nature and impacts of EU Cohesion Policy.

In order to develop this discussion the structure and logic of the book is organised as follows. In Chapter 2 we begin by discussing the major features of the regional and urban economies of the European Union, comparing them where relevant to their counterparts in the US and elsewhere in order to provide a reference scale. In Chapter 3 we examine the workings and impacts of the policy, and the combination of the material discussed in Chapters 1,2 and 3 then provides the basis for the policy reform debates examined in Chapter 4. Chapter 4 explains the place-based issues and challenges raised by the Barca (2009) report, and discusses in detail the ensuing EU Cohesion Policy reforms which have been implemented as a result of these debates. In the post-crisis era, of the three Europe 2020 growth dimensions it is the role played by policy in fostering smart growth that is seen as being critical to the recovery of Europe. Therefore Chapter 5 discusses the case for innovation policies being implemented at the level of the region, and this provides the grounding for the discussion of the EU 'smart specialisation' agenda discussed in Chapter 6. The high profile EU smart specialisation agenda has generated a great deal of interest in many countries and regions leading to a widespread level of public awareness of the role which well-designed Cohesion Policy interventions can play in fostering development. Although the smart specialisation approach originally emerged from a slightly different intellectual arena to the place-based issues raised in the Barca (2009) report, as we will see in Chapter 5 the smart specialisation concept dovetails very closely with all of the other thinking underpinning the reform of EU Cohesion Policy. Smart specialisation is widely regarded as being a spearhead of the policy reform agenda and its perceived importance in the new policy approach requires a chapter in its own right. Lastly Chapter 7 offers some final observations and conclusions. 


\section{NOTES}

1. In US\$ at current prices and Purchasing Power Parities (OECD 2014).

2. The estimates of Nobel Laureate Robert Fogel (1964) put this figure at 2.7 per cent of Gross National Product GDP although David (1969) and Donaldson and Hornbeck (2013) put the figure at closer to 5 per cent or above.

3. See Chapter 2 for details.

4. http://www.transtasman-review.productivity.govt.nz/sites/default/files/14-trans-tasmansupplementarye.pdf

5. North American Free Trade Agreement http://www.cfr.org/trade/naftas-economic-impact/ p15790 https://www.fas.org/sgp/crs/row/R42965.pdf

6. See Timmer et al. (2010) Table 5.7 page 175; Van Ark et al. (2012) Table 3.5 page 78.

7. See also: http://ec.europa.eu/internal_market/top_layer/historical_overview/background_en.htm http://ec.europa.eu/internal_market/publications/docs/20years/achievements-web_en.pdf http://www.cpb.nl/publicatie/de-interne-markt-en-de-nederlandse-economie-implicatiesvoor-handel-en-economische-groei http://nieuwsuur.nl/onderwerp/313318-euro-levert-extra-weeksalaris-op.html http://www.dbresearch.com/PROD/DBR_INTERNET_EN-PROD/PROD00000000003228 97/The+Single+European+Market+20+years+onpercent3A+Achievements, +unfulfilled+ expectations+percent $26+$ further+potential.pdf http://www.kas.de/wf/doc/kas_34913-1522-2-30.pdf?130716135256

8. http://www.oilandgasuk.co.uk/2013-economic-report.cfm

9. http://www.cepii.fr/PDF_PUB/lettre/2011/let316ang.pdf

10. The Europe 2020 strategy was launched with headline targets and seven 'flagship initiatives' being included as part of the strategy, which are aimed at highlighting key themes which Europe needs to urgently address. These relate to innovation, digital economy, the mobility of young people, employment, poverty, resource efficiency and industrial policy. See: http://ec.europa.eu/europe2020/europe-2020-in-a-nutshell/index_ en.htm

11. See: http://www.oecd.org/document/10/0,3746,en_2649_201185_42393354_1_1_1_1,00. html

12. As reflected in the 2014 Richard Dimbleby Lecture entitled 'A New Multilateralism for the Twenty First Century' given by the Managing Director of the IMF Christine Lagarde on 03.02.2014 http://www.imf.org/external/np/speeches/2014/020314.htm and also by the reports of the Commission on Growth and Development published by the World Bank (2008, 2010a,b) and Stiglitz et al. (2009).

13. National Intelligence Council (NIC) (2012).

14. See:

http://www.whitehouse.gov/sites/default/files/omb/assets/memoranda_2010/m10-21.pdf http://www.whitehouse.gov/blog/2010/06/30/place-based-investments http://www.eda.gov/pdf/CEDS_Flyer_Wht_Backround.pdf http://yosemite.epa.gov/opa/admpress.nsf/0/75E1F57EB6D0FCEC8525788CA0063A5CB

15. http://report.mitigation2014.org/spm/ipcc_wg3_ar5_summary-for-policymakers_approved. pdf

16. Stiglitz et al. (2009).

'Monitoring economic performance, quality of life and sustainability' jointly produced by the French 'Conseil d'analyse économique' and the German Council of Economic Experts, December 2010. Available at: http://www.cae.gouv.fr/IMG/pdf/095_ANG.pdf

17. http://ec.europa.eu/regional_policy/consultation/5cr/index_en.cfm 